Apidologie, 1983, 14 (3), 225-232.

\title{
NATIVE AND DISSOCIATED PROTEIN PATTERNS OF LARVAL FOOD OF HONEY BEES (APIS MELLIFERA CECROPIA L.)
}

\author{
Andreas T. THRASYVOULOU \\ Aristotle University. School of Agriculture \\ Laboratory of Apiculture and Sericulture \\ Thessaloniki-Greece
}

\section{SUMMARY}

The changing patterns of honey bee larval food proteins were studied during larval life with polyacrylamide disc electrophoresis. When sodium dodecyl sulfate detergent was used the number of protein bands increased from 10 to 15 in worker jelly, from 8 to 10 in royal jelly and from 11 to 13 in drone jelly. Patterns of older worker and drone larval diet were more complex than those of queen larval diet. Comparing the results with a previous analysis, slight differences in protein patterns between two races of bees (A. Mellifera cecropia and $A$. mellifera liqustica) were found.

\section{INTRODUCTION}

Extensive knowledge on protein changes throughout larval development would be of great help in elucidating the processes which control the caste differentiation of honey bees.

The proteins of honey bee haemolymph have been examined extensively in the larval and adult stage (LIU and DiXON 1965, LENSKY 1967, GILLIAM and JACKSON 1972, Bounias 1975). The enzymatic activity of haemolymph during caste development (Tripathi and Dixon 1968, 1969) and the protein patterns of hypopharyngeal gland (HALBERSTADT 1980) were also studied.

Comparative analyses of protein constituents of honey bee larval food showed some contradictory conceptions. HABOWSKY and SHUEL (1959) reported a pronounced fading of the protein bands in the diet of older worker larvae. PATEL et al. (1960) found that worker jelly of older larvae had less protein bands (spots) 
than the diet of young larvae. On the other hand Tomoda et al. (1977) postulated that the same electrophoretic patterns were found in worker and royal jelly, while Thrasyvoulou (1982) found an increase in the number of protein bands of older worker larvae. Differences may be due to analytical techniques to the race of honey bees, to seasonal, hive or other variables.

In this study, the protein patterns of honey bee larval food collected from Greek colonies (Apis mellifera cecropia) were examined electrophoretically (native proteins). Subsequently the proteins were exposed to a disulfide bond reducing agent which yields individual polypeptide chains (dissociated proteins) and the new patterns were correlated to the age, caste, sex and race of the larvae receiving the food.

\section{MATERIALS AND METHODS}

Samples of honey bee larval food were collected in successive intervals over twenty developmental ages of worker, queen and drone larvae. The contents of twenty worker cells, twenty drone cells and a single queen cell were used for each sample. Appoximately $0.20 \mathrm{ml}$ distilled water was thoroughly mixed with the larval food of the cells, drawn up into Pasteur pipette and transfered into vials. Samples were centrifuged for 10 minutes at $2500 \mathrm{rpm}(450 \times \mathrm{G})$. The supernatant liquid was filtered through a $0.45 \mu$ Millipore filter, brought to $6.0 \mathrm{ml}$ with distilled water and stored in a freezer $\left(-20 \pm 2{ }^{\circ} \mathrm{C}\right)$ until analyzed.

The larva of each cell was weighed and the age of each was estimated with the aid of equations for growth rates of honey bees (ThrasYvoulou and BENTON 1982).

Twenty five micrograms of protein was used for each electrophoretic gel. This amount was estimated spectrophotometrically as described by LOWRY et al. (1951) with lysozyme as a standard. A Canalco Model 24 polyacrylamide gel disc electrophoresis apparatus was used for separation. Power supply (Model $13014 \mathrm{~A}$ ) was adjusted to $6 \mathrm{~mA}$ per electrophoretic tube.

Electrophoretic separations of native proteins were made as proposed by ORNSTEIN and DAvIES (1962). The lower or separating gel contained $7.5 \%$ acrylamide. Beta-Alanine acetic acid buffer at a running $\mathrm{pH} 4.5$ was used. Protein bands were stained with $0.04 \%(\mathrm{~W} / \mathrm{V})$ Coomassie brilliant blue G-250 dye in $5 \%$ perchloric acid as described by REISNER et al. (1975).

Electrophoretic separations of dissociated proteins were carried out as described by WEBER and OSBORN (1975) using $0.5 \mathrm{M}$ sodium phosphate dibasic, at $\mathrm{pH} 7.0$ as buffer. The lower gel was $10 \%$ acrylamide. Each sample consisted of larval food protein, glycerol, $0.1 \%$ bromophenol blue in buffer, and $10 \%$ sodium dodecyl sulfate (SDS) with $1 \% 2$-mercaptoethanol in a ratio $7: 1: 1: 1$. Samples were heated in a boiling water bath for 2-5 minutes. Following separation, protein bands were stained for one hour with a solution consisting of $250 \mathrm{mg}$ Conmassie brilliant blue G-250, $45 \mathrm{ml}$ distilled water, $45 \mathrm{ml}$ methanol and $9.2 \mathrm{ml}$ glacial acetic acid.

Mobilities of polypeptide chains were plotted versus the known molecular weights of phosphorylase (100,000 M.W.), catalase (58,000 M.W), carbonic anhydrase (29,000 M.W.), myoglobin (17,200 M.W.) and lysozyme (14,300 M.W.) standards on semilogarithmic paper. The standard curve was used to estimate molecular weights of polypeptide chains from larval diets.

The samples where collected from the Aristotle University apiary during the summer of 1982 and were analyzed in the Pesticide Research Laboratory of Pennsylvania State University. 


\section{RESULTS AND DISCUSSION}

Native proteins. Figure 1 gives the position and Rf-values of protein bands that characterize the diet of honey bee larvae. A code number (1-11) was assigned to each band according to its mobility. Bands with the number $1,2,3,5,6,7,8$, were sharp and well stained by Coomassie blue dye, while bands with the number 4, 9, 10 and 11 were very faint. Only those bands that were clearly shown on the gels were recorded. Number 5 and 6 had almost equal mobility. Generally, these two bands were well separated, but in a few cases they appeared as one. The same was true with the bands numbered 7 and 8 .

Native Protein

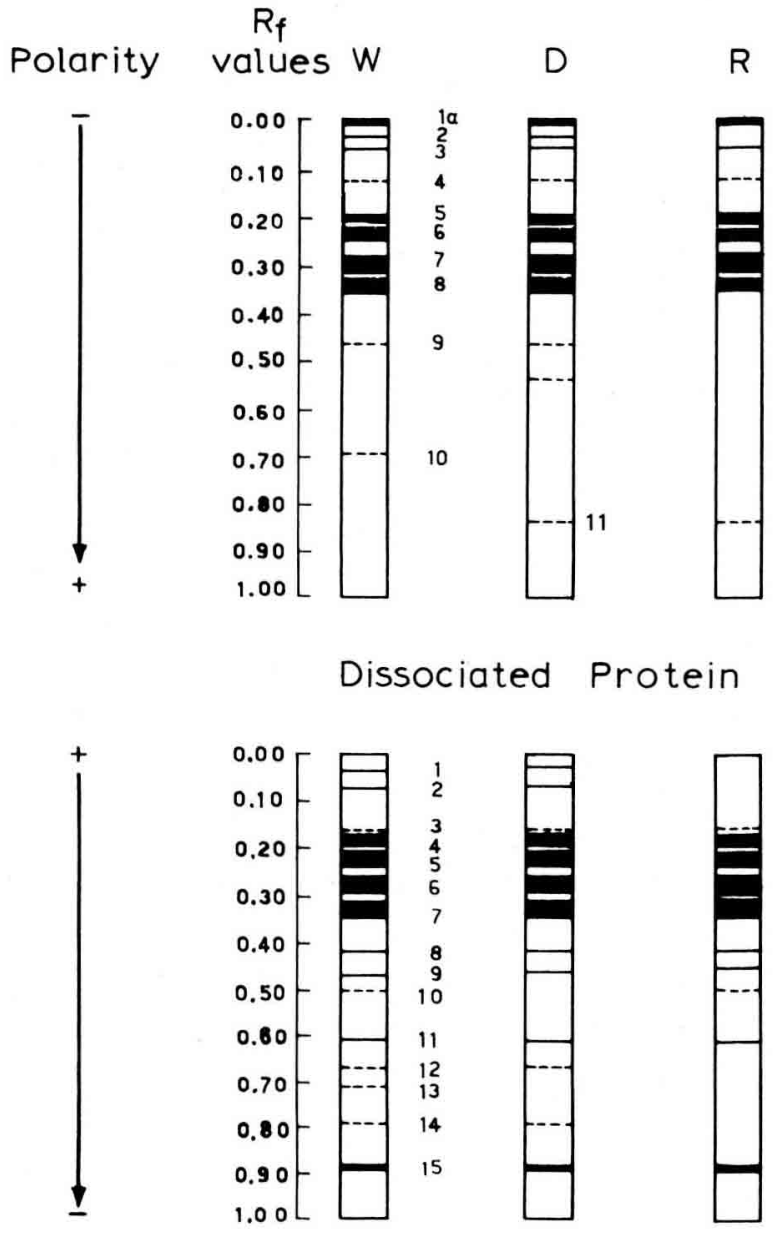

Fici. 1. - Native and dissociated water soluble protein patterns of honey bee larval food. $\mathrm{W}=$ worker jelly; $\mathrm{D}=$ drone jelly; $\mathrm{R}=$ royal jelly; $\alpha=$ number of protein bands. 
TABL. 1. - Electrophoretic protein bands of native proteins from larval food their Rf-values and their percent occurence in 60 samples.

\begin{tabular}{|c|c|c|c|c|c|c|c|c|c|c|}
\hline \multirow{3}{*}{$\begin{array}{c}\text { Protein } \\
\text { Band } \\
\text { No. }\end{array}$} & \multirow{3}{*}{$\begin{array}{c}\mathrm{Rf} \\
\text { value }^{\mathrm{a}}\end{array}$} & \multicolumn{9}{|c|}{$\begin{array}{l}\% \text { occurrence of protein bands } \\
\text { by age of larval development }\end{array}$} \\
\hline & & \multicolumn{3}{|c|}{$6-37 \mathrm{hr}^{\mathrm{b}}$} & \multicolumn{3}{|c|}{$38-73 \mathrm{hr}^{\mathrm{b}}$} & \multicolumn{3}{|c|}{$74-130 \mathrm{hr}^{\mathrm{b}}$} \\
\hline & & W & $\mathbf{R}$ & D & W & $\mathbf{R}$ & D & W & $\mathbf{R}$ & $\mathrm{D}$ \\
\hline 1 & $0.01 \pm 0.000$ & 100 & 100 & 100 & 100 & 100 & 100 & 100 & 100 & 100 \\
\hline 2 & $0.03 \pm 0.009$ & 0 & - & 0 & 40 & - & 20 & 100 & - & 100 \\
\hline 3 & $0.07 \pm 0.013$ & 100 & 100 & 100 & 100 & 100 & 100 & 100 & 100 & 100 \\
\hline 4 & $0.13 \pm 0.009$ & 100 & 100 & 100 & 100 & 100 & 100 & 100 & 100 & 100 \\
\hline 5 & $0.22 \pm 0.008$ & 100 & 100 & 100 & 100 & 100 & 100 & 100 & 100 & 100 \\
\hline 6 & $0.26 \pm 0.023$ & 100 & 100 & 100 & 100 & 100 & 100 & 100 & 100 & 100 \\
\hline 7 & $0.34 \pm 0.037$ & 100 & 100 & 100 & 100 & 100 & 100 & 100 & 100 & 100 \\
\hline 8 & $0.37 \pm 0.037$ & 100 & 100 & 100 & 100 & 100 & 100 & 100 & 100 & 100 \\
\hline 9 & $0.65 \pm 0.041$ & 15 & - & 20 & 20 & - & 20 & 60 & - & 60 \\
\hline 10 & $0.73 \pm 0.069$ & 15 & - & 0 & 20 & - & 0 & 60 & 10 & 80 \\
\hline 11 & $0.86 \pm 0.042$ & - & - & 0 & - & - & 10 & - & - & 30 \\
\hline
\end{tabular}

a. Means and standard error $(p=0.05)$ of twenty samples (each sample was replicated three times).

b. Percentage was based on twenty samples from each developmental period.

$\mathrm{W}=$ worker jelly, $\mathbf{R}=$ royal jelly, $\mathrm{D}=$ drone jelly.

Table 1 shows the Rf-values and their percentage present for each development stage. The whole period of larval development was grouped into three shorter periods for easier presentation of the results.

During the first $37 \mathrm{hr}$ of larval age, seven protein bands $(1,3,4,5,6,7)$ were found in all the samples of worker, royal and drone jelly. The percentage occurence of the rest of the bands was either zero $(2,11)$ or very small $(9,10)$. Between $38-73 \mathrm{hr}$ of larval development, the number of protein bands increased in worker and drone jelly. During this period, band 2 appeared in $40 \%$ of the worker jelly and in $20 \%$ of drone jelly samples. The earliest this band appeared was $65 \mathrm{hr}$ into worker and $71 \mathrm{hr}$ into drone larval development. Later band 2 was found consistently in all the samples and band 3 became sharp and more distinct. After $74 \mathrm{hr}$ worker and drone larvae are fed with a diet that showed more protein bands than before. Band 2 was found in all the samples, while the frequency in occurence of bands 9,10 and 11 was increased. The number of protein bands remained unchanged in royal jelly during the entire feeding period.

THRASYVOULOU (1982) reported the protein patterns of honey bee larval food collected from Italian colonies. Comparing the patterns of the two races of bees (cecropia and ligustica) the following similarities were noted. In both races there was (a) an increase in the number of protein bands of worker and drone jelly as larvae developed (b) band 2 appeared only in the diet of older larvae; (c) band 3 became sharp in the diet of older larvae; (d) the number of bands in royal jelly remained 
unchanged during the whole developmental period. Larval food collected from Italian bees had three consistent protein bands while larval food collected from Greek bees had seven. This was so because bands with close mobilities $(5,6$ and 7,8$)$ considered as subunits were reported as single bands in Italian bees. Yet, bands numbered 3 and 4 were found in all samples of Greek bees but not in all the samples of Italian bees.

Dissociate proteins. Fifteen polypeptide chains were found in the diet of worker larvae, thirteen in the diet of drone larvae and ten in the diet of queen larvae. Their position and $\mathrm{Rf}$-values are given in Figure 1. Bands numbered 2, 4, $5,6,7,8,9,11$ and 15 were well separated and stained while bands $3,10,12,13$ and 14 were faint. Table 2 shows the Rf-values, molecular weights and occurence of polypeptide chains. As was the case with native proteins, some bands were present in all samples of worker, drone and queen larvae $(4,5,6,7,8,9,11)$. A few bands were found only in the diets of older worker and drone larvae ( 1 and 2$)$ and some

TABL. 2. - Electrophoretic protein bands of dissociated proteins from larval food their Rf-values, molecular weight, their percent occurence in 60 samples.

\begin{tabular}{|c|c|c|c|c|c|c|c|c|c|c|c|}
\hline \multirow{3}{*}{$\begin{array}{c}\text { Protein } \\
\text { Band } \\
\text { No. }\end{array}$} & \multirow{3}{*}{$\begin{array}{c}\text { Rf } \\
\text { values }\end{array}$} & \multirow{3}{*}{$\begin{array}{c}\text { Approximate }^{\mathrm{b}} \\
\text { Molecular } \\
\text { Wieght } \times 10^{4}\end{array}$} & \multicolumn{9}{|c|}{$\begin{array}{l}\% \text { occurrence of protein bands } \\
\text { by age of larval development }\end{array}$} \\
\hline & & & \multicolumn{3}{|c|}{$6-37 \mathrm{hr}^{\mathrm{c}}$} & \multicolumn{3}{|c|}{$38-73 \mathrm{hr}^{\mathrm{c}}$} & \multicolumn{3}{|c|}{$74-130 \mathrm{hr}^{\mathrm{c}}$} \\
\hline & & & $\mathbf{W}$ & $\mathrm{R}$ & D & $\mathbf{W}$ & $\mathbf{R}$ & $\mathrm{D}$ & $\mathbf{W}$ & $\mathbf{R}$ & D \\
\hline 1 & $0.05 \pm 0.011$ & 10.00 & 0 & - & 0 & 20 & - & 10 & 100 & - & 80 \\
\hline 2 & $0.15 \pm 0.070$ & 10.00 & 0 & - & 0 & 30 & - & 10 & 60 & - & 80 \\
\hline 3 & $0.18 \pm 0.040$ & 8.45 & 40 & 60 & 0 & 45 & 50 & 10 & 100 & 50 & 100 \\
\hline 4 & $0.24 \pm 0.033$ & 7.67 & 100 & 100 & 100 & 100 & 100 & 100 & 100 & 100 & 100 \\
\hline 5 & $0.29 \pm 0.035$ & 6.83 & 100 & 100 & 100 & 100 & 100 & 100 & 100 & 100 & 100 \\
\hline 6 & $0.35 \pm 0.035$ & 6.05 & 100 & 100 & 100 & 100 & 100 & 100 & 100 & 100 & 100 \\
\hline 7 & $0.40 \pm 0.052$ & 5.34 & 100 & 100 & 100 & 100 & 100 & 100 & 100 & 100 & 100 \\
\hline 8 & $0.44 \pm 0.059$ & 4.78 & 100 & 100 & 100 & 100 & 100 & 100 & 100 & 100 & 100 \\
\hline 9 & $0.51 \pm 0.052$ & 3.83 & 100 & 100 & 100 & 100 & 100 & 100 & 100 & 100 & 100 \\
\hline 10 & $0.57 \pm 0.017$ & 3.19 & 40 & 20 & - & 40 & 20 & - & 50 & 50 & - \\
\hline 11 & $0.62 \pm 0.151$ & 2.36 & 100 & 100 & 100 & 100 & 100 & 100 & 100 & 100 & 100 \\
\hline 12 & $0.68 \pm 0.083$ & 1.48 & 20 & - & - & 60 & - & - & 80 & - & - \\
\hline 13 & $0.75 \pm 0.057$ & 1.40 & 10 & - & 10 & 30 & - & 60 & 30 & - & 75 \\
\hline 14 & $0.86 \pm 0.059$ & 1.40 & 80 & - & 50 & 60 & - & 60 & 80 & - & 90 \\
\hline 15 & $0.92 \pm 0.059$ & 1.40 & 100 & 100 & 10 & 100 & 100 & 60 & 100 & 100 & 100 \\
\hline
\end{tabular}

a. Means ans standard error $(\mathrm{p}=0.05 \%)$ of twenty samples (each sample was replicated three times)

b. Based on molecular weights of standard protein plot.

c. Percentage was based on twenty samples from each developmental period. $\mathbf{W}=$ worker jelly, $\mathrm{R}=$ royal jelly, $\mathrm{D}=$ drone jelly.

other bands were not consistent, but their occurence increased with the age of worker and drone larvae $(3,13,14)$. 
The protein patterns of the native system were compared to that of the dissociate system. The seven consistent native protein bands increased to eight when dissociated. There was no increase in the two bands that appeared in the diet of older worker and drone larvae (including band number 3-sharp), and the inconsistent protein bands increased from two to five. These results suggest that the majority of protein fractions of larval food of honey bees may consist of single polypeptides.

The external nutritional source may influence to a great extent the haemolymph composition of larvae (CHEN, 1966). In many insects, the ingested protein must first be catabolized into amino acids before being absorbed (HousE, 1974). TSAO and SHUEL (1968) showed that royal jelly proteins pass through the midgut as a mixture of polypeptides and a minor proportion as amino acids. They also found that haemolymph of worker larvae at 72 ht had more protein bands than at $60 \mathrm{hr}$. Yet they indicated that throughout larval life, queen larval had fewer haemolymph protein fractions than worker larvae. It seems that there is a relationship between the number of protein bands in larval food and the protein bands of haemolymph of worker larvae at $72 \mathrm{ht}$ had more protein bands than at $60 \mathrm{hr}$. Yet complex as development of worker larvae proceeds. The diet of worker larvae had more protein bands than the diet of queen larvae.

The increase in number of protein bands in worker and drone jelly is followed by an increase in enzymatic activity in the diet (THrasYvoulou, 1982). Enzymatic activity remains the same in queen larvae. Some of the additional bands in the diet of older worker or drone larvae may functio as enzymes. A further study of larval food proteins would be useful to understand both their morphogenetic meaning and their potential role in caste differentiation.

\section{ACKNOWLEDGEMENTS}

I would like to thank Dr. A. W. BENTON for providing all the necessary facilities and reagents to carry out this research.

Received for publication in February 1983.

\footnotetext{
RÉSUMÉ

SPECTRE DES PROTÉINES GLOBALES ET DISSOCIÉES DE LA NOURRITURE LARVAIRE DES ABEILLES ( APIS MELLIFICA CECROPIA L.)

Les spectres protéiques de la nourriture larvaire des abeilles prélevée dans des colonies grecques (Apis mellifica cecropia) ont été corrélés avec l'âge, la caste, le sexe et la race des larves qui recevaient la nourriture.
} 
Chaque échantillon comportait la nourriture larvaire de 20 cellules d'ouvrières, 20 cellules de mâle et une cellule royale. On a prélevé au total 60 échantillons au cours des stades successifs de développement des larves d'ouvrières, de mâle et de reine. Le prélèvement et le traitement des échantillons avant l'analyse ont été faits selon THRasyvoulou (1982). On a pesé la larve de chaque cellule et estimé leur âge à l'aide des équations de taux de croissance des abeilles (Thrasyvoulou et BENTON, 1982). Les protéines totales de chaque échantillon ont été déterminées par la méthode de LowRY et al. (1951) et pour chaque gel d'électrophorèse on a utilisé $25 \mu \mathrm{g}$ de protéines. La séparation des protéines globales a été faite par électrophorèse sur disque de polyacrylamide (ORNSTEIN et DAvıES, 1962). Le gel inférieur renfermait 7,5\% d'acrylamide. L'acide acétique bêta-alanine a été utilisé comme tampon au $p \mathrm{H} \mathrm{4,5}$ et les bandes ont été colorées selon la méthode décrite par REISNER et al. (1975). Les séparations électrophorétiques des protéines dissociées ont été faites selon la méthode décrite par WEBER et OSBORN (1975) en utilisant comme tampon au pH 7 le phosphate de sodium dibasique à $0,5 \mathrm{M}$ et comme détergent le sulfate dodécyl de sodium (SDS).

Les larves d'ouvrières et de mâles reçoivent à partir de 74 heures une nourriture qui possède un nombre croissant de bandes protéiniques. Durant toute la période de nourrissement, les larves de reine reçoivent une nourriture dont le spectre protéique reste constant. Ces résultats concordent avec ceux obtenus à partir de la nourriture larvaire prélevée dans des colonies italiennes (THRASYvouLOU, 1982).

Lorsqu'on a utilisé le SDS, le nombre de bandes protéiniques est passé de 10 à 15 pour la gelée d’ouvrières, de 8 à 10 pour la gelée royale et de 11 à 13 pour la gelée de mâles. Ceci laisse à penser que la majorité des fractions protéiniques de la nourriture larvaire des abeilles consiste en polypeptides uniques.

\section{ZUSAMMENFASSUNG}

\section{PROTEINMUSTER VON NATÜRLICHEN UND AUFGETRENNTEN PROTEINEN IM LARVENFUTTER DER HONIGBIENEN}

(APIS MELLIFERA CECROPIA L.)

Die Proteinmuster des aus griechischen Bienenvölkern (Apis mellifera cecropia) entnommenen Larvenfutters korrelieren mit dem Alter, der Kaste, dem Geschlecht und der Rasse der gefütterten Larve.

Das Larvenfutter von zwanzig Arbeiterinnenzellen, zwanzig Drohnenzellen oder einer Weiselzelle bildete eine Probe. Insgesamt wurden 60 Proben genommen in der Reihenfolge des Entwicklungsstadiums von Arbeiterinnen, Drohnen und Königinnen. Die Sammlung und Behandlung der Proben vor der Analyse erfolgte gemäB Thrasyvoulou (1982). Die Larve aus der jeweiligen Zelle wurde gewogen und ihr Alter gemäß der Gleichung der Wachstumsrate (THRASYvouLOU and BENTON 1982) bestimmt. Das Gesamtprotein jeder Probe wurde nach der Methode von LowRY et al. (1951) bestimmt und $25 \mu \mathrm{g}$ des Proteins zur Elektrophorese verwandt. Die Auftrennung des natürlichen Proteins erfolgte mit Polyacrylamid Disc Elektrophorese (Davis 1962). Das untere Gel enthielt 7,5\% Acrylamid. Beta-Alanin Essigsäure wurde als Puffer bei pH 4,5 verwendet und die Banden, wie bei REISNER et al. (1975) beschrieben, gefärbt. Die elektrophoretische Auftrennung der zerlegten Proteine erfolgte nach WeBER und OsBorn (1975) unter Verwendung von $0,5 \mathrm{M}$ di-Natriumhydrogenphosphat bei $p \mathrm{H} 7.00 \mathrm{und}$ Dodecylhydrogensulfat Natriumsalz (SDS) als Detergenz.

Arbeiterinnen- und Drohnenlarven werden mit einem Futter gefüttert, das bei $74 \mathrm{~h}$ alten Larven eine erhöhte Anzahl von Proteinbanden zeigt. Das Futter der Königinnenlarven zeigt ein unverändertes Proteinmuster während der gesamten Fütterungsperiode. Diese Ergebnisse entsprechen denen, die bei der Untersuchung des Larvenfutters von italienischen Völkern (ThrasYvoulou 1982) erzielt wurden.

Wenn SDS benutzt wurde, erhöhte sich die Anzahl der Proteinbanden von 10 auf 15 bei Arbeiterinnenfutter, von 8 auf 10 bei Weiselfutter und von 11 auf 13 bei Drohnenfutter. Dies weist darauf hin, daß die Mehrzahi der Proteinfraktionen des Larvenfutters von Honigbienen aus einfachen Polypeptiden besteht. 


\section{BIBLIOGRAPHY}

BoUnIAS M., 1975. - Les protéines de l'hémolymphe chez l'abeille Apis mellifica mellifica L. Apidologie, 6 (3), 207-218.

CHEN P. S., 1966. - Amino acid and protein metabolism in insect development. 3,53-132. In Advances in insect Physiology. Academic Press. London and New York, 382.

Gilliam M. and Jackson K., 1972. - Proteins of developing worker honey bees, Apis mellifera. Ann. Entomol. Soc. Am., 65 (2), 516-517.

HABOWSKY J. E. J. and SHUEL R. W., 1959. - Separation of the protein constituents of the larval diets of the honeybee by continuous paper electrophoresis. Can. J. Zool., 37, 964.

HALBERSTADT K., 1980. - Elektrophoretische Untersuchungen zur Sekretionstätigkeit der Hypopharynxdrüse der Honigbiene (Apis mellifera L.). Insectes Sociaux, 27 (1), 61-67.

House H. L., 1965. - Insect nutrition and digestion. 769-900. In Physiology of Insecta ed M. Rockstein New York London Academic Press.

LENSKY Y., 1967. - separation and identification of larval bee workers' (Apis mellifera L. var. ligustica Spin) blood proteins. Proc. XXIst Int. Apicultural Congr., Sci. Sessions, Sec. Biol. Univ. of Maryland.

LiU T. P. and Dixon S. E., 1965. - Studies in the mode of action of royal jelly in honey bee development. VI haemolymph protein changes during caste development. Can. J. Zool., 43, 873-879.

Lowry O. H., Rosebrough N. J., Farr A. L. and Randall R. J., 1951. - Protein measurement with the folin phenol reagent. Biol. Chem., 193, 256-275.

Ornstein L., Davies B. J., 1962. - Disc electrophoresis. Reprint by Distillation Products Industries, Rochester, NY. 41.

Patel G. N., Haydak M. H., Gochnauer T. A., 1960. - Electrophoretic components of the proteins in honeybee larval food. Nature, London, 186, 633-634.

Reisner A. H., Nemes P. and Bucholtz C., 1975. - The use of Coomassie brilliant blue G 250 perchloric acid solution for staining in electrophoresis and isoelectric focusing on polyacrylamide gels. Analytical Biochemistry, 64, 509-516.

Thrasyvoulou A. T., 1982. - Biochemical and biological aspects of honey bee (Apis mellifera L.) larval food. Ph. D. Thesis. The Pennsylvania State University. $208 \mathrm{p}$.

Thrasyvoulou A. T. and Benton A. W., 1982. - Rates of growth of honey bee larvae. J. Apic. Res., $21(4), 189-192$.

Tomoda G., Matsuyama J. and Matsuka M., 1977. - Studies on protein in roya! jelly. 2. Fractionation of water-soluble by DEAE-cellulose chromatography, gel filtration and disc electrophoresis. J. Apic. Res., 16 (3), 125-130.

Tripathi R. K. and Dixon S. E., 1968. - Haemolymph esterases in the female larval honeybee. Apis mellifera L., during caste development. Can. J. Zool., 46, 1013-1017.

TRIPATHI R. K. and DiXON S. E., 1969. - Changes in some haemolymph dehydrogenase isozymes of the female honeybee, Apis mellifera L., during caste development Can. J. Zool., 47, 763-770.

TSAO W. and Shuel R. W., 1968. - Breakdown of royal jelly protein in the midgut of the larval honey bee. J. Apic. Res., 7 (3), 119-128.

Weber K. and Osborn M., 1975. - Proteins and dodecyl sulfate : Molecular weight determination on polyacrylamide gels and related procedures. In the Proteins, Vol. 1, 170-223. Academic Press, New York. 